\title{
Hypothesis: Possible idiotypic suppression of cell-mediated immunity in lepromatous leprosy
}

\author{
J FERLUGA, ${ }^{*}$ V COLIZZI, $\dagger$ A FERRANTE, $\ddagger$ \\ M J COLSTON $\S \&$ E J HOLBOROW**
}

*Department of Immunology, London Hospital Medical College, London, UK; †Institute of Microbiology, University of Pisa, Pisa, Italy; $\ddagger$ University Department of Paediatrics, The Adelaide Children's Hospital Inc., Adelaide, Australia; §Laboratory for Leprosy and Mycobacterial Research, National Institute for Medical Research, London, UK; **Bone and Joint Research Unit, London Hospital Medical College, London, UK

\begin{abstract}
Accepted for publication 5 March 1984
Summary It is suggested that lepromatous leprosy may develop as a result of chronic suppression of specific cellular immunity by anti-idiotypic (Id) antibodies and Id-restricted suppressor lymphocytes. This potential immuno-tolerizing mechanism would probably be initiated most effectively in early life. Auto-anti-Id responses may be induced by exposure to Mycobacterium leprae antigens, or maternal anti-Id antibodies may be acquired transplacentally. The anti-Id antibodies would be directed against a predominant self-antigenic idiotype located on immuno-recognition molecules for $M$. leprae antigens on lymphocyte membranes. Together with certain HLA-self-antigens such Id-anti-Id responses would determine the susceptibility to leprosy.
\end{abstract}

\section{Introduction and hypothesis}

Patients with tuberculoid leprosy develop granulomatous hypersensitivity, while in the lepromatous form of the disease cell-mediated immunity to Mycobacterium leprae, though not to other organisms, is deficient. ${ }^{1}$ This probably allows the bacterium to replicate in macrophages and to disseminate, in spite of an elevated humoral immune response. It is not clear to what extent this defect is primary or secondary; most polar lepromatous patients present with evidence of having 'downgraded' from the borderline or tuberculoid end of the spectrum, whereas others present with evidence of having developed lepromatous disease a priori. In addition, whereas treatment of borderline patients might result in 'upgrading' 
reactions, ${ }^{2}$ in which specific immunological parameters appear to increase, polar lepromatous patients retain complete anergy towards $M$. leprae in spite of effective chemotherapy. Several mechanisms of immuno-suppression arising during infections have been suggested. ${ }^{3,4}$ Recently, it has been found that auto-anti-idiotypic (Id) antibodies induced during the immune response to various antigens, and in some infections, may temporarily or permanently suppress specific humoral or cellular immunity..$^{5-7}$

Our hypothesis is that during infection with $M$. leprae, an anti-Id response against an idiotype predominant in determining immunity to $M$. leprae is induced. This anti-Id immune response may be responsible, at least in part, for the anergic lepromatous form of the disease.

\section{Experiment and clinical data}

Idiotypes are self-antigenic epitopes located on lymphocyte receptors and antibody molecules. ${ }^{8}$ The combination of an anti-Id antibody with an idiotypic receptor stimulates the Id-bearing lymphocyte. This is equivalent to, but independent of the stimulation that results from the combination of the nominal antigen with the specific recognition site located on the same cell receptor. Hence anti-Id antibody may by itself induce or prime for an immune response in a positive or negative way, to an associated nominal antigen, and vice versa..$^{9,10}$ According to the network theory proposed by Jerne, ${ }^{11}$ antigen, by expanding the specific clone, also augments the associated idiotype. The latter then as antigen induces a feedback anti-Id response in the form of anti-Id antibodies and anti-Id receptor-bearing cells which regulates immunity to nominal antigen by stimulating Id-bearing helper and suppressor $\mathrm{T}$ cells. A given idiotype specificity may be shared by a set of immunoglobulin molecules and $\mathrm{B}$ and $\mathrm{T}$ cells, thus linking different cell components in their response to nominal antigen. ${ }^{8}$ Inheritable predominant Id specificities can occur on the majority of antibodies against particular antigens, such as the Id-T15 in Balb/c mice immunized with phosphorylcholine or with pneumococcal polysaccharide which has the same antigenic determinant and the Id-A5A in A/J mice immunized with a streptococcal A antigen. It has been suggested that predominant Id-restricted responses depend on the functioning of two types of helper cells - one restricted by the major histocompatibility gene complex (MHC) (ie, by Ia molecules expressed on the surface of antigen-presenting macrophage-like cells), the other restricted by the Id genes which code for the variable region of the heavy chains of immunoglobulin molecules and possibly also for T cell receptors. ${ }^{12,13}$ In this way the Id-genes would function in concert with $\mathrm{MHC}$ genes to determine and direct the immune response to a particular antigen. Interactions between genes determining Gm allotype and HLA locus antigens have been demonstrated for 
antibody responses to a Salmonella flagellin antigen, ${ }^{14}$ and in the rat there is evidence of linkage between idiotypes and heavy chain allotypes. ${ }^{15}$

It has been shown that anti-Id-T15 antibodies, which are otherwise stimulatory, when injected into neonatal Balb/c mice suppress chronically and possibly for life the appearance of $\mathrm{T}$ and $\mathrm{B}$ cell functions related to this idiotype. ${ }^{16}$ In adult $\mathrm{A} / \mathrm{J}$ mice, combined treatment with anti-Id-A5A antibodies and streptococcal antigen produces chronic suppression of most of the anti-streptococcus antibody response. ${ }^{8}$ Feedback suppression by anti-Id antibodies of autoantibodies against acetylcholine receptors in myasthenia gravis ${ }^{17}$ and of antibodies to DNA in systemic lupus erythematosus patients ${ }^{18}$ has also been inferred. Furthermore, transient anti-Id antibodies reacting with anti-tetanus toxoid immunoglobulins have been found in individuals receiving booster inoculations. ${ }^{5}$ These anti-Id antibodies inhibit the in vitro production of anti-toxoid antibodies by $\mathrm{B}$ lymphocytes.

Auto-anti-Id antibodies have also been shown to react with the receptors expressed on $\mathrm{T}$ cells involved in delayed type hypersensitivity responses. Both $\mathrm{T}$ effector cells and $\mathrm{T}$ suppressor cells, which regulate contact sensitivity, may be blocked by anti-Id antibodies. ${ }^{19}$ Auto-anti-Id antibodies are also induced in the course of $M$. bovis (BCG) infection in mice. ${ }^{6}$ Their presence in the serum is responsible for the inhibition of passive transfer of delayed type hypersensitivity to PPD of tuberculin in heavily BCG-infected animals and for the specific anergy they display. In another study, immune serum from mice infected with Nocardia brasiliensis, probably containing anti-idiotypic antibodies, promoted infection with this organism in mice. ${ }^{20}$

\section{Relevance of anti-Id response to leprosy}

In lepromatous leprosy one defect in cellular immunity apparently lies in specific helper T cells and their ability to produce interleukin-2. ${ }^{21}$ Although some authors have been able to demonstrate suppressor factors in lepromatous leprosy associated both with macrophages ${ }^{22,23}$ and with T-cells, ${ }^{24}$ others have been unable to demonstrate the presence of antigen-specific suppressor T-cells. ${ }^{25}$ It is possible that in the extreme (polar) form of lepromatous leprosy in which the immunodeficiency is not drug reversible, the function of both subsets of specific $T$ cells is abolished or their development is prevented by anti-Id antibodies in the same way as anti-Id-T15 produces its effects in neonatal mice. ${ }^{16}$ Alternatively, the suppression of helper cells for cell-mediated immunity may be perpetuated by a long-lived, Id-restricted suppressor cell population similar to that in the $\mathrm{A} / \mathrm{J}$ mice ${ }^{8}$ which may have remained undetected in leprosy studies as has been suggested previously. ${ }^{26}$ This type of suppressor cell bearing either the Id or the anti-Id receptor, may be distinct from the HLA (MHC) restricted cells described elsewhere. ${ }^{24}$ Inheritance of the appropriate HLA genes and of the genes 
responsible for the putative predominant Id associated with immunity to $M$. leprae, perhaps combined with exposure to anti-Id antibody from immune or infected mothers during embryonic life, may lead to a chronic specific defect of immunity. In mice it has been shown that mothers suppressed for the expression of Id-T15 confer the unresponsiveness to their offspring via anti-Id antibodies. ${ }^{16}$ In later life, auto-anti-Id antibodies may be induced and boosted by prolonged exposure to $M$. leprae antigens. The Id-bearing anti- $M$. leprae antibodies, alone or complexed to antigen, would be especially effective in restimulating both anti-Id antibodies and anti-Id receptor bearing suppressor cells..$^{27,28}$

In lepromatous leprosy humoral immunity may be also suppressed initially if associated with a predominant (inherited germline) idiotype. However the suppression of the latter may be bypassed by recruitment of alternative, individual Id-specificities which are also associated with anti-M. leprae antibodies, as has been shown in mice in relation to other antigens. ${ }^{16,28}$ This would not be expected with cellular immunity which appears to be more restricted in idiotype than humoral. ${ }^{10,28}$

An important relevant finding from family studies in man is that idiotypes shared between rheumatoid factors in different individuals are inherited independently of HLA genes. ${ }^{29}$ Such non-HLA linked inheritance of the presumptive $M$. leprae associated predominant Id may explain the lack of correlation between and incidence of lepromatous leprosy and HLA product frequencies. ${ }^{30-32}$ In Indian familial studies, a correlation with HLA-DR2 containing haplotypes has been found in siblings suffering from tuberculoid leprosy, but only in families where the parents were healthy, ${ }^{30}$ whereas in a study carried out in South America HLA-DR3 appeared to be associated with the immunological response to infection with leprosy. ${ }^{32}$ Where similar studies were carried out on affected children of affected parents, no significant associations with HLA tissue haplotypes were found. In such families, the children may have passively acquired maternal anti-Id antibodies or have been exposed to $M$. leprae antigens and thus produced auto-anti-Id antibodies. In either case, the anti-Id antibodies may have induced transient suppression, allowing the infection to establish itself. Such anti-Id responses, whether or not of predominant type, might well swamp susceptibility effects due to HLA type. In experiments on congenic mouse strains it has been shown that the Balb non-H-2 (MHC) background in combination with $\mathrm{H}-2^{\mathrm{k}}$ haplotype genes, ie in Balb/K mice, favours dissemination of $M$. leprae murium infection. ${ }^{33}$ A possible predominant Id which would be coded by $\mathrm{V}_{\mathrm{H}}$ genes of the immunoglobulin (Ig 1) region on chromosome 12, may be encompassed in the genetic non-MHC background. The influence of Id genes would thus be distinct from that of the susceptibility genes to various intracellular parasites, which are known to be present on chromosome 1 and which are non-specific. ${ }^{33}$ These latter genes probably determine the activation and bactericidal capacity of macrophages in the early, innate resistance phase of infection. In the acquired, immunological phase of resistance or susceptibility, macrophages 
are recruited and activated further, in concert with the early mechanisms, by lymphokines from stimulated $\mathrm{T}$ lymphocytes, which are in turn regulated by genes of the MHC (on chromosome 17 in the mouse), and possibly also by Id-genes.

This general explanation is in harmony with the accepted view that multiple genetic factors control susceptibility to leprosy. ${ }^{34}$

Immunosuppression by an anti-Id response or by maternally transmitted anti-Id antibody, especially in early life, which has been suggested as one mechanism of immunological tolerance,$^{35}$ may thus also be important for the development of lepromatous leprosy. Compatible with this view is the finding that some persons free of the clinical disease but having contact with it develop a specific humoral response to $M$. leprae, but unlike other contacts, do not develop a delayed hypersensitivity skin reaction to lepromin. ${ }^{1,36}$ Exposure to a particular environmental antigen may play a critical role in the development and expression of a predominant Id. ${ }^{13}$ Thus, a given infection may develop owing to a secondary immune response generating presumptive long-lived Id-restricted antigen-specific suppressor memory cells. Perhaps more often, a protective primary or an anamnestic response of helper memory cells, also associated with a predominant Id, may occur and the infection may pass subclinically. It has been suggested that among transplacentally transmitted protective anti-malaria antibodies there may be anti-Id antibodies which prevent infants in endemic areas from mounting immunity to malaria during natural exposure ${ }^{37}$ Suppressive priming for leprosy by anti-Id antibodies may not be as readily apparent owing to the long incubation period, low infectivity and unequal exposure to $M$. leprae. Nevertheless, foetal exposure to maternal anti- $M$. leprae antibodies and mycobacterial antigens has been demonstrated. ${ }^{38}$ Similar considerations may apply to other infections in which cellular immunity appears deficient, such as disseminated cutaneous and visceral (kala azar) leishmaniasis, chronic mucocutaneous candidiasis, fulminating tuberculosis and hepatic and extrahepatic infection with hepatitis B virus. ${ }^{1,}, 39$ Such antigen driven specific tolerizing conditions are distinct from primary immunodeficiencies due to inborn defects in the development of an entire lymphocyte set or subsets.

\section{Acknowledgments}

We are grateful to Professor J L Turk, Dr Jill Curtis and Dr V D Ramanathan for suggestions and discussion.

\section{References}

1 Turk JL, Bryceson ADM. Immunological phenomena in leprosy and related diseases. Adv Immunol, 1971; 13: 209-66. 
${ }^{2}$ Barnetson RStC, Barnetson A, Pearson JMH, Kronvall G. Does non-specific T lymphocyte stimulation of B lymphocytes occur during $\mathrm{r}$ reversal reaction in borderline leprosy? Scand $J$ Immunol, 1976; 5: 287-91.

3 Bullock WE. Anergy and infection. Adv Intern Med, 1975; 21: 149-73.

${ }^{4}$ Colizzi V, Ferluga J, Garreau F, Malkovsky M, Asherson GL. Suppressor cells induced by BCG release non-specific factors in vitro which inhibit DNA synthesis and interleukin-2 production. Immunology, 1983; in press.

${ }^{5}$ Geha RS. Presence of circulation anti-idiotype-bearing cells after booster immunization with tetanus toxid (TT) and inhibition of anti-TT antibody synthesis by auto-anti-idiotypic antibody. J Immunol, 1983; 130: 1634-9.

6 Colizzi V, Giuntini M, Garzelli C, Campa M, Falcone G. Auto-anti-idiotypic antibodies inhibit T cell mediated hypersensitivity in BCG-infected mice. Cell Immunol, 1983; 80: 205-10.

7 Massman Rose L, Goldman M, Lambert PH. Simultaneous induction of an idiotype, corresponding anti-idiotypic antibodies, and immune complexes during African trypanosomiasis in mice. J. Immunol, 1982; 128: 79-85.

8 Eichman K. Expression and function of idiotypes on lymphocytes. Adv Immunol, 1978; 26: 195-254.

9 Eichman K, Rajewsky K. Induction of T and B cell immunity by anti-idiotypic antibody. Eur $J$ Immunol, 1975; 5: 661-6.

10 Thomas WR, Moraha G, Miller JFA. Induction of suppressor T cells by monoclonal anti-idiotope antibody in strains of mice not expressing the idiotype in hyperimmune serum. $J$ Immunol, 1983; 130: 2079-82.

11 Jerne NK. Towards a network theory of the immune system. Ann Immunol (Inst Pasteur), 1974; 125C: $373-89$.

12 Sercarz E, Wicker L, Stratton J, Miller A, Metzger D, Maizels R, Katz M, Harvey M, Benjamin C. Regulation of antibody specificity and idiotype by two independent $T$ cells. In Immunoglobulin Idiotypes. Janeway C, Sercarz EE, Wigzell H (eds), Acad Press 1981, pp 533-46.

${ }^{13}$ Bottomly K. Activation of the idiotypic network: Environmental and regulatory influences. In Immunoglobulin Idiotypes. Janeway C, Sercarz EE, Wigzell H. (eds), Acad Press 1981, pp 517-32.

14 Whittingham S, Mathews JD, Schanfield MS, Matthews JV, Tait BD, Morris PJ, Mackay IR. Interactive effect of Gm allotypes and HLA-B locus antigens on the human antibody response to a bacterial antigen. Clin Exp Immunol, 1980; 40; 8-15.

15 Binz $\mathrm{H}$, Wigzell $\mathrm{H}$, Bazin $\mathrm{H}$. T cell idiotypes are linked to immunoglobulin heavy chain genes. Nature, 1976; 264: 639.

${ }^{16}$ Cosenza H, Julius M, Augustin AA. Idiotypes as variable region markers: analogies between receptors on phosphorylcholine-specific T and B lymphocytes. Immunol Rev, 1977; 34: 3-1 18.

17 Dwyer DR, Bradley RJ, Urquhart CK, Kearney JH. Naturally occurring anti-idiotypic antibodies in myasthenia gravis patients. Nature, 1983; 301: 611-14.

18 Abdou NI, Wall H, Lindsley HB, Halsey JF, Susuki T. Network theory in autoimmunity. Invitro suppression of serum anti-DNA antibody binding to DNA by anti-idiotypic antibody in systemic lupus erythematosus. J Clin Invest, 1981; 67: 1297-1304.

19 Moorhead JW. Antigen receptors on murine $\mathrm{T}$ lymphocytes in contact sensitivity III. Mechanism of negative feedback regulation by auto-anti-idiotypic antibody. J Exp Med, 1982; 155: 820-30.

${ }^{20}$ Rico G, Ochoa R, Oliva A, Gonzalez-Mendoz A, Walker SM, Ortiz-Ortiz L. Enhanced resistance to Nocardia brasiliensis infection in mice depleted on antigen-specific B cells. $J$ Immunol, 1982; 129: 1688-93.

${ }^{21}$ Heregewoin A, Godal T, Mustafa AS, Belehu A, Yemaneberhan T. T cell conditioned media reverse T cell unresponsiveness in lepromatous leprosy. Nature, 1983; 303: 342-4. 
${ }^{22}$ Salgame PR, Mahadevan PR, Antia NH. Mechanism of immunosuppression in leprosy: presence of suppressor factor(s) from macrophages of lepromatous leprosy patients. Infect Immun, 1983, 40: 1119-26.

${ }^{23}$ Nath I, van Rood JJ, Mehra NK, Vaidya MC. Natural suppressor cells in human leprosy: the role of HLA-D identical peripheral lymphocytes and macrophages in the in vitro modulation of lymphoproliferative responses. Clin exp Immunol, 1980; 42: 203-10.

${ }^{24}$ Mehra V, Convit J, Rubinstein A, Bloom BR. Activated suppressor T cells in leprosy. J Immunol, 1982; 129: 1946-52.

${ }^{25}$ Stoner GL, Mshana RN, Touw J, Belehu A. Studies on the defect in cell-mediated immunity in lepromatous leprosy using HLA-D identical siblings. Absence of circulating suppressor cells and evidence that the defect is in the $\mathrm{T}$ lymphocyte rather than the monocyte population. Scand J Immunol, 1982; 15: 33-48.

${ }^{26}$ Stoner GL, Touw J, Atlaw T, Belehu A. Antigen-specific suppressor cells in subclinical leprosy infection. Lancet, 1981; ii: 1372-7.

${ }^{27}$ Klaus GGB. Antigen-antibody complexes elicit anti-idiotypic antibodies to self-idiotopes. Nature, 1978; 272: 265-6.

${ }^{28}$ Sy MS, Bach BA, Dohi Y, Nisonoff A, Benacerraf B, Greene MI. Antigen and receptor driven regulatory mechanisms. I. Induction of suppressor T cells with anti-idiotypic antibodies. $J$ Exp Med, 1979; 150: 1216-28.

${ }^{29}$ Pasquali JL, Fong S, Tsoukes C, Vaughan JH, Carson DA. Inheritance of immunoglobulin M rheumatoid-factor idiotypes. J Clin Invest, 1980; 66: 863-6.

${ }^{30}$ Fine PEM, Wolf E, Pritchard J, Watson B, Bradley DJ, Festenstein H, Chacko CJG. HLA linked genes and leprosy: a family study in Karigiri, South India. J Infect Dis, 1979; 140: 152-61.

31 Van Eden W, de Vries RRP, Mehra NK, Vaidya MC, D’Amaro J, Van Rood JJ. HLA segregation of tuberculoid leprosy: confirmation of the DR2 marker. J Infect Dis, 1980; 141: 693-701.

32 Van Eden W, de Vries RRP, Van Rood JJ. HLA and infectious diseases. Human Genetics, Alan R Liss Inc 1982 Part B Medical Aspects pp 37-54.

${ }^{33}$ Curtis J, Adu HO, Turk JL. H-2 linkage control of resistance to subcutaneous infections with Mycobacterium leprae murium. Infect Immun, 1982; 38: 434-9.

34 Serjeantson SW. HLA and susceptibility to leprosy. Immunological Rev, 1983; 70: 89-112.

35 Mullbacher A. Natural tolerance: a model for Ir gene effects in the cytotoxic T cell response to H-Y. Transplantation, 1981; 32: 58-60.

${ }^{36}$ Bharadwaj VP, Ramu G, Desikan KV. A preliminary report on sub-clinical infection in leprosy. Leprosy in India, 1982; 54: 220-7.

${ }^{37}$ Harte PG, De Souza JB, Playfair JHL. Failure of malaria vaccination in mice born to immune mothers. Clin exp Immunol, 1982; 49: 509-16.

${ }^{38}$ Melsom R, Duncan ME, Harboe M, Bjune B. Antibodies against Mycobacterium leprae antigen 7 from birth to 18 months of age: an indicator of intrauterine infection in leprosy. Clin exp Immunol, 1980; 42: 107-13.

${ }^{39}$ Valdimarsson H, Giggs JM, Wells RS, Yamamura M, Hobbs JR, Holt PJL. Immune abnormalities associated with chronic mucocutaneous candidiasis. Cell Immunol, 1973; 6: $348-61$. 